\title{
Anatomy of a telescoped pull-apart basin: an example from the Cambro-Ordovician rocks in the Antigonish Highlands of Nova Scotia
}

\author{
J. Duncan Keppie \\ Department of Mines and Energy, P.O. Box 1087 \\ Halifax, Nova Scotia B3J $2 X 1$
}

and

\author{
J.B. Murphy \\ Department of Geology, St. Francis Xavier University \\ Antigonish, Nova Scotia B2G 1 CO
}

Date Received December 7, 1987

Date Accepted April 20, 1988

\begin{abstract}
Cambrian-Lower Ordovician rocks outcrop in the northernmost Antigonish Highlands where they unconformably overlie the Precambrian Georgeville Group. They are divided into two groups that are interpreted to be lateral facies equivalents. The Iron Brook Group is predominantly sedimentary and consists of red clastic sedimentary rocks, pink limestones containing late Early Cambrian fossils, quartzites, calcareous tuffs and ironstones containing Late Cambrian-Ordovician inarticulate brachiopods. The McDonalds Brook Group consists of red clastic sedimentary rocks at the base overlain by bimodal, alkalic, continental rift volcanic rocks with minor interlayered red clastic rocks and late Early Cambrian fossiliferous pink limestones. These rocks are inferred to have been deposited in a pull-apart basin produced in the overlap zone between two dextral NE-trending faults. Connection between the pull-apart basin and a larger ocean is indicated by cosmopolitan, open-ocean, Early Cambrian trilobites.

Cambro-Ordovician rocks in the central part of the basin were subsequently thrusted (?)northeastwards and then back thrusted. Associated NW-SE folds verge away from a central zone. This complex structure dies out towards the NE and SW ends of the basin, where the lowest Cambrian units are relatively mildly deformed and the basal unconformity with Precambrian rocks is preserved. These structures are inferred to have been produced by sinistral motion on the NE-SW bounding faults with compression concentrated locally in the pull-apart basin. This movement expelled Cambro-Ordovician rocks lying on attenuated continental lithosphere from the basin centre onto the basin margins thereby accounting for the limited extent of the deformation. These structures are truncated by the sub-Silurian unconformity, thereby constraining the time of deformation to the Ordovician. Both the Cambro-Ordovician and Siluro-Devonian were deformed during the Devonian by upright NE-SW folds that are preferentially developed adjacent to the major NE-SW faults. The folds are consistently oriented slightly anticlockwise of the faults thereby indicating renewed dextral movements on the NE-SW faults.
\end{abstract}

Des roches du Cambrien à l'Ordovicien inférieur affleurent dans la région la plus au nord des Monts Antigonish et recouvrent en discordance le Groupe précambrien de Georgeville. Elles constituent deux groupes interprétés comme des équivalents latér aux de faciès. Le Groupe d'Iron Brook est surtout de nature sédimentaire et se compose de roches sédimentaires clastiques rouges, de calcaires roses renfermant des fossiles du début de l'Éocambrien, des quartzites, des tufs calcaires et des roches ferrugineuses contenant des brachiopodes inarticulés tardicambriens à ordoviciens. Le Groupe de McDonalds Brook comprend des roches sédimentaires clastiques rouges en sa base, surmontées par des volcanites bimodales alcalines, de type rift continental et englobant quelques niveaux à roches clastiques rouges et calcaires roses à fossiles de la fin de l'Éocambrien. Ces dépôts se seraient accumulés à l'intérieur d'un bassin rhomboédrique sur décrochement installé dans un îlot en distension formé par l'intersection de deux failles dextres orientées NE. La présence de trilobites cosmopolites et franchement marins du début du Cambrien prouve que ce bassin était en large communication avec la haute mer.

Dans la partie centrale du bassin, les roches cambro-ordoviciennes furent par la suite chevauchées (?vers le nord-est) puis rétrochevauchées. S'y associent des plis NO-SE dont la vergence s'éloigne d'une zone centrale. Cette structure complexe s'estompe vers les extrémités $\mathrm{NE}$ et $\mathrm{SO}$ du bassin, là où la déformation des roches cambriennes initiales est relativement modeste et la discordance basale avec les roches précambriennes est préservée. Ces structures seraient le produit d'un jeu senestre des accidents bordiers NE-SO, conjugué à une concentration locale du serrage dans le bassin de décrochement. Ce mouvement expulsa des roches cambro-ordoviciennes, sises sur une lithosphère continentale amincie, du centre vers les abords de la cuvette, ce qui explique leur faible déformation. Le recoupement de ces mêmes structures par la discordance angulaire antésilurienne cantonne la déformation à l'Ordovicien. Tant le Cambro-Ordovicien que le Siluro-Dévonien furent déformés lors du Dévonien par des plis droits NE-SO développés de façon préférentielle au voisinage des failles majeures NE-SO. L'orientation de ces plis s'inscrit, 
conformément, selon une faible rotation dans le sens inverse des aiguilles d'une montre par rapport aux failles, ce qui suggère un rejeu dextre des failles NE-SO.

[Traduit par le journal]

\section{INTRODUCTION}

The Antigonish Highlands lie in the Avalon Zone of the Canadian Appalachians (Williams, 1978) and form one of the terranes that were amalgamated in latest Precambrian to form the Avalon Composite Terrane (Keppie, 1982a, b ; 1985). The Antigonish Highlands are bounded to the northwest by the Hollow Fault, to the south by the Chedabucto Fault and to the east by the Devono-Carboniferous Antigonish basin. The highlands consist predominantly of the Late Precambrian Georgeville Group, which consists of mafic and felsic volcanic rocks, marble, slate, wacke and conglomerate. Cambro-Ordovician rocks in the Antigonish Highlands are limited to a small area in the northernmost highlands bounded by the Hollow Fault on the northwest and the Greendale Fault on the southeast, although the latter is locally obscured beneath overstepping sequences and thrust slices (Fig. 1). They are lithologically and faunally typical of the Avalon Zone. These rocks unconformably overlie the Georgeville Group from which they are lithologically, stratigraphically, structurally and geochemically distinct (Murphy and Keppie, 1987). During the remapping of these rocks, fossils were discovered that were identified by Landing et al. (1980) as Early

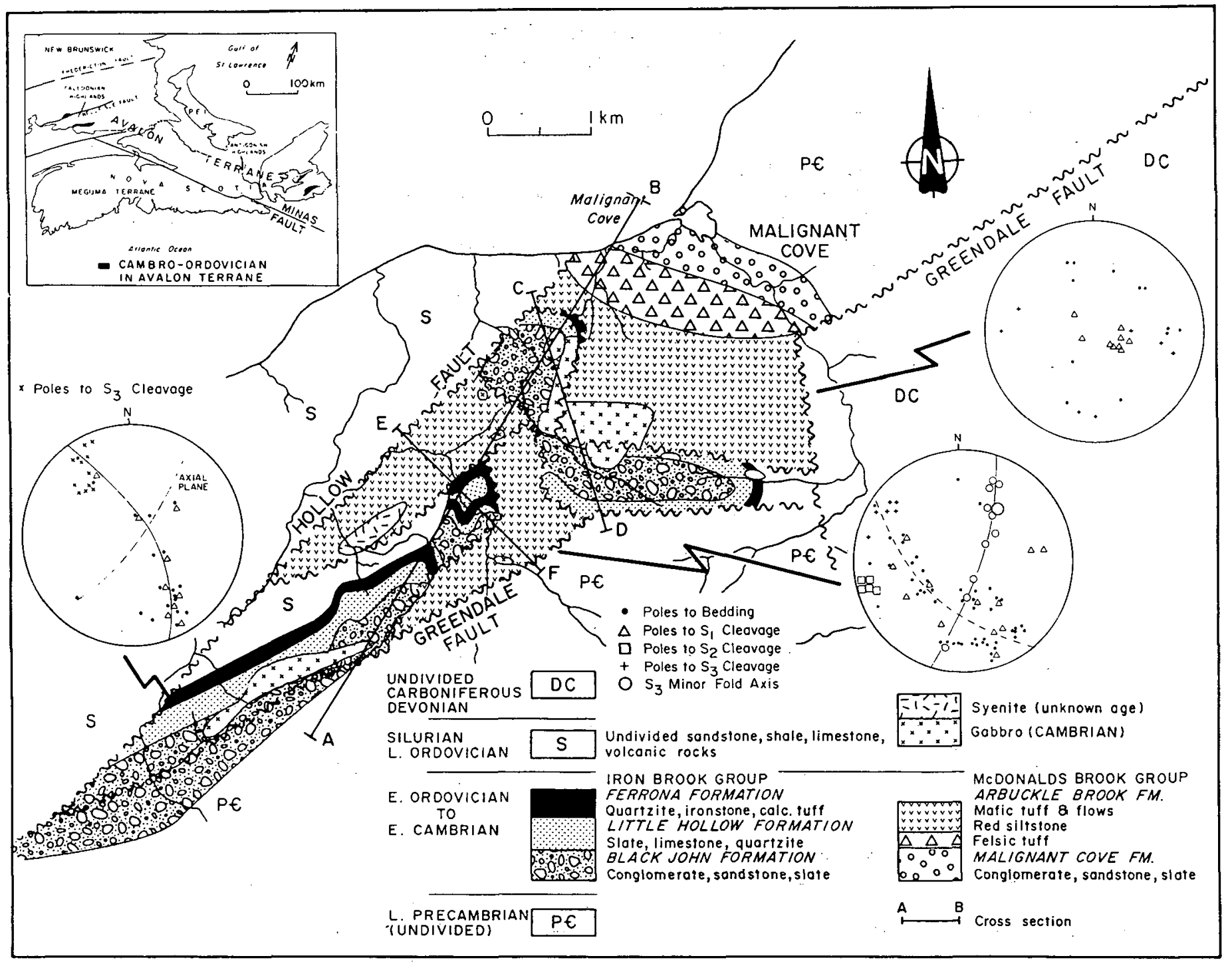

Fig. 1. Simplified geological map of the Cambrian to Lower Ordovician rocks in the Antigonish Highlands (modified after Murphy et al., 1982). Stereoplots show structural data from the western, central and eastern parts of the area. The three cross-sections located on the map are shown on Figure 2. Inset shows distribution of Cambrian rocks in the Avalon Zone of Nova Scotia. 
Cambrian in age. This paper presents a complete revision of the Cambro-Ordovician stratigraphy, map boundaries and structure. The Cambro-Ordovician rocks are overlain with angular unconformity by Late Ordovician to Early Devonian rocks of the Arisaig Group (Murphy, 1987). Late Precambrian to DevonoCarboniferous plutonic rocks, predominantly consisting of gabbro and granite occur throughout the Highlands.

\section{PREVIOUS WORK}

In the area shown on Figure 1, Williams (1914) distinguished five pre-Silurian units (from base to top): (1) greywacke, slate and ironstone (James River Formation); (2) red and grey sandstone and slate (Baxters Brook Formation); (3) rhyolite; (4) conglomerate (Malignant Cove Formation); and (5) basalt. The James River and Baxters Brook formations were included in the Browns Mountain Group, which was deformed by upright folds and metamorphosed prior to the deposition of the Malignant Cove Formation. The rhyolite and basalt were intruded into the Browns Mountain Group during the Early Ordovician and Mississippian, respectively. The James River Formation was presumed to be Early Ordovician based upon the occurrence of Obolus (Linulobus) spissa and Lingulella (?) in the ironstone and associated sandstone.

Subsequently Benson $(1967,1970,1974)$ mapped 6 units in the area of Figure 1: (1) Baxters Brook Formation (siltstone, argillite, minor andesite); (2) Brierly Brook Formation (andesite); (3) Little Hollow Formation (siltstone, quartzite, minor ferruginous wacke); (4) intrusive diorite; (5) Malignant Cove Formation (conglomerate, wacke); and (6) Silurian Beechill Cove Formation (wacke, siltstone) containing crinoid stems and indeterminable brachiopods on Iron Brook. Units 1-3 were included in the Browns Mountain Group which was inferred to be Cambro-Ordovician based upon the age of inarticulate brachiopods in the ironstones of the Little Hollow Formation. The Browns Mountain Group was deformed during the Taconian orogeny and was then unconformably overlain first by the Malignant Cove Formation and then by the Siluro-Devonian rocks. All of these units were deformed during the Acadian orogeny, uplifted and eroded and then unconformably overlain by Devono-Carboniferous rocks.

During 1976 and 1977, detailed work in the Arisaig and Georgeville areas and reconnaissance of the entire Antigonish Highlands produced two significant discoveries (Keppie, 1978). Firstly, early recumbent folds were discovered in the Browns Mountain Group (Murphy et al., 1982). These folds predated the intrusion of a post-tectonic alaskite stock yielding a Rb-Sr whole rock isochron age of $535 \pm 13 \mathrm{MA}$ (R.F. Cormier, written communication, 1981) and a K/Ar age on muscovite of $604 \pm 14 \mathrm{Ma}(\mathrm{R} . \mathrm{K}$. Wanless, personal communication, 1978). Secondly, a rich, previously unrecorded fauna was discovered in the pink limestones underlying the ironstones. This fauna was subsequently determined to be Early Cambrian (Landing et al., 1980). These observations implied that there were several groups of rocks in what was the Browns Mountain Group: an older group now called the Georgeville Group that must be Precambrian, and a younger Cambro-Ordovician sequence which, following remap- ping (Murphy et al., 1982) has been assigned to the predominantly sedimentary Iron Brook and the mainly volcanic McDonalds Brook groups (Figs. 1, 2). The recovery of Early Cambrian faunas from both groups indicates that they are facies equivalents. These groups were subsequently brought together by thrusting (Figs. 1, 2).

\section{STRATIGRAPHY}

The coloured geological map of the northern Antigonish Highlands (Murphy et al., 1982) is superior to the black-andwhite Figures 1 and 3 for locating type sections referred to in the text.

\section{Iron Brook Group}

Iron Brook is the type section of two of the three formations of the Iron Brook Group.

\section{Black John Formation}

Field Relationships. The Black John Formation crops out mainly at the southwestem end of the area underlain by CambroOrdovician rocks (Fig. 1). Its type section occurs in the western branches of both Doctor's and Iron brooks, with other good sections on McKinnons Brook and in Little Hollow (Figs. 1,3,4). It consists predominantly of red conglomerate, red sandstone, red and green siltstone and slate with minor rhyolite. The base of the formation is exposed on the West Branch of Doctor's Brook (Figs. 1,3,4) where a $6 \mathrm{~m}$ thick red rhyolitic tuff overlies green slates of the Maple Ridge Formation, one of the lower units of the Late Precambrian Georgeville Group (Murphy and Keppie, 1987). The green slates dip steeply to the southeast, whereas the rhyolite dips to the northwest and overlying conglomerates young northwards. Consideration of the regional stratigraphy indicates that this contact represents a major unconformity. The top of the Black John Formation is also exposed in the type section, where it is defined as the base of the lowest limestone bed.

The thickness of the Black John Formation appears to be 500 $m$ thick on the West Branch of Doctor's Brook. However, this estimate is complicated by the presence of small thrusts which become more common towards the top of the unit, and a displacement of unknown magnitude along the high angle Greendale Fault.

In the West Branch of Iron Brook a thin rhyolitic unit is in fault contact with the Maple Ridge Formation to the south. The rhyolite is massive and aphanitic, but has a brecciated appearance in the field. The rhyolite is concordantly overlain by red conglomerates which are well-sorted, polymictic, clast-supported, trough cross-bedded, cleaved and contain subrounded to subangular pebbles (up to $1 \mathrm{~cm}$ in size) of red siltstone, red slate, metabasalt, green slate, granite with graphic texture, quartz and perthitic feldspar. Some of these pebbles are similar in composition to the underlying Georgeville Group. These conglomerates are interbedded with red, cross-bedded sandstones. Upwards, these conglomerates and sandstones become progres- 


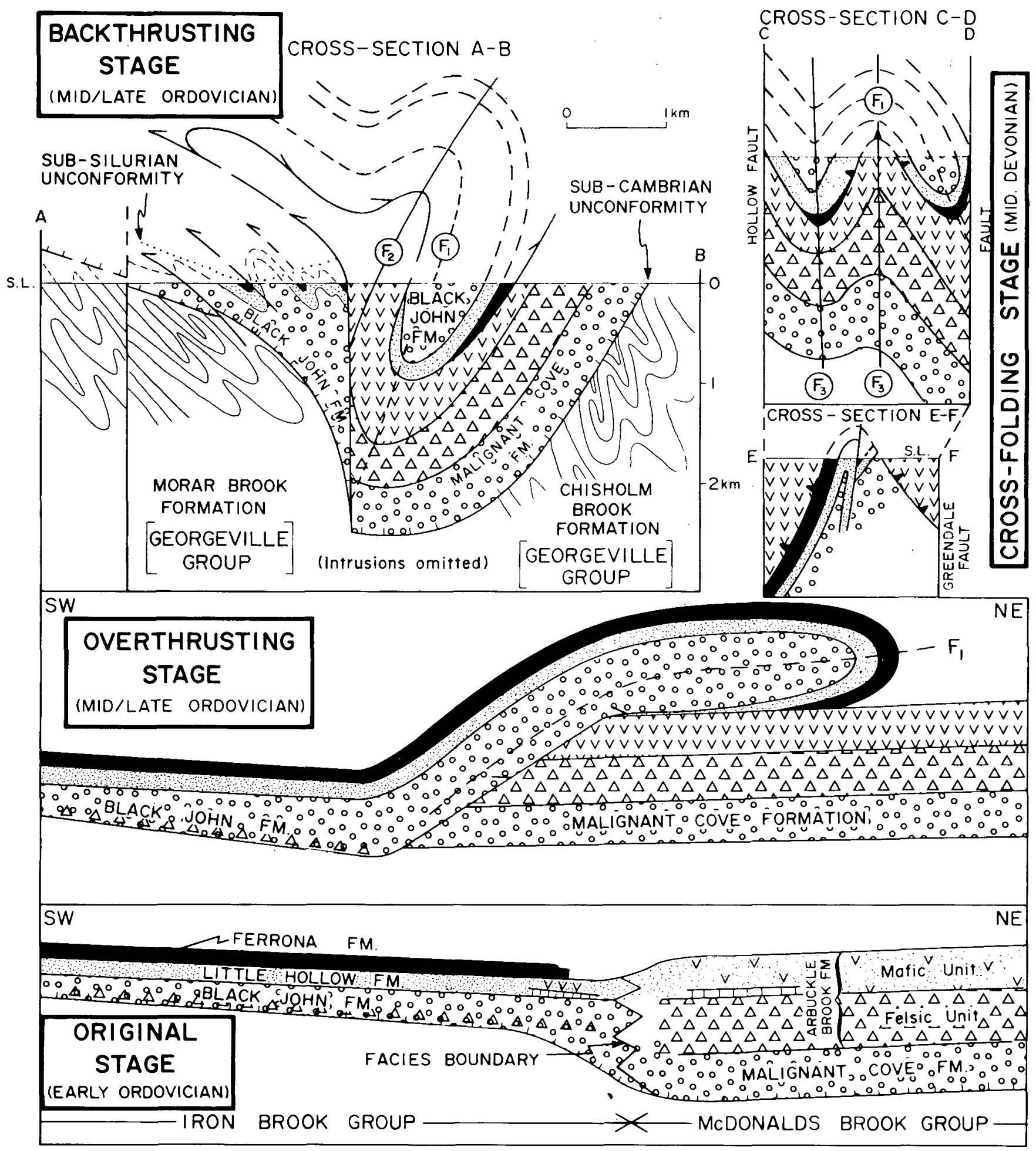

Fig. 2. Successive stages of deformation of Cambro-Ordovician rocks in the Antigonish Highlands: (1) original stage immediately following deposition of the Cambro-Early Ordovician rocks depicting the facies change between the Iron Brook and McDonalds Brook groups; (2) the overthrusting stage (mid to late Ordovician) in which the Iron Brook Group is thrust northeastwards over the McDonalds Brook Group; (3) the backthrusting stage depicted by cross-section A-B where thrusting to the southwest is accompanied by folding verging outw ards from a central zone; (4) a cross-folding stage (mid-Devonian) depicted by cross-section C-D and E-F where NE-SW folds deform the rocks. 


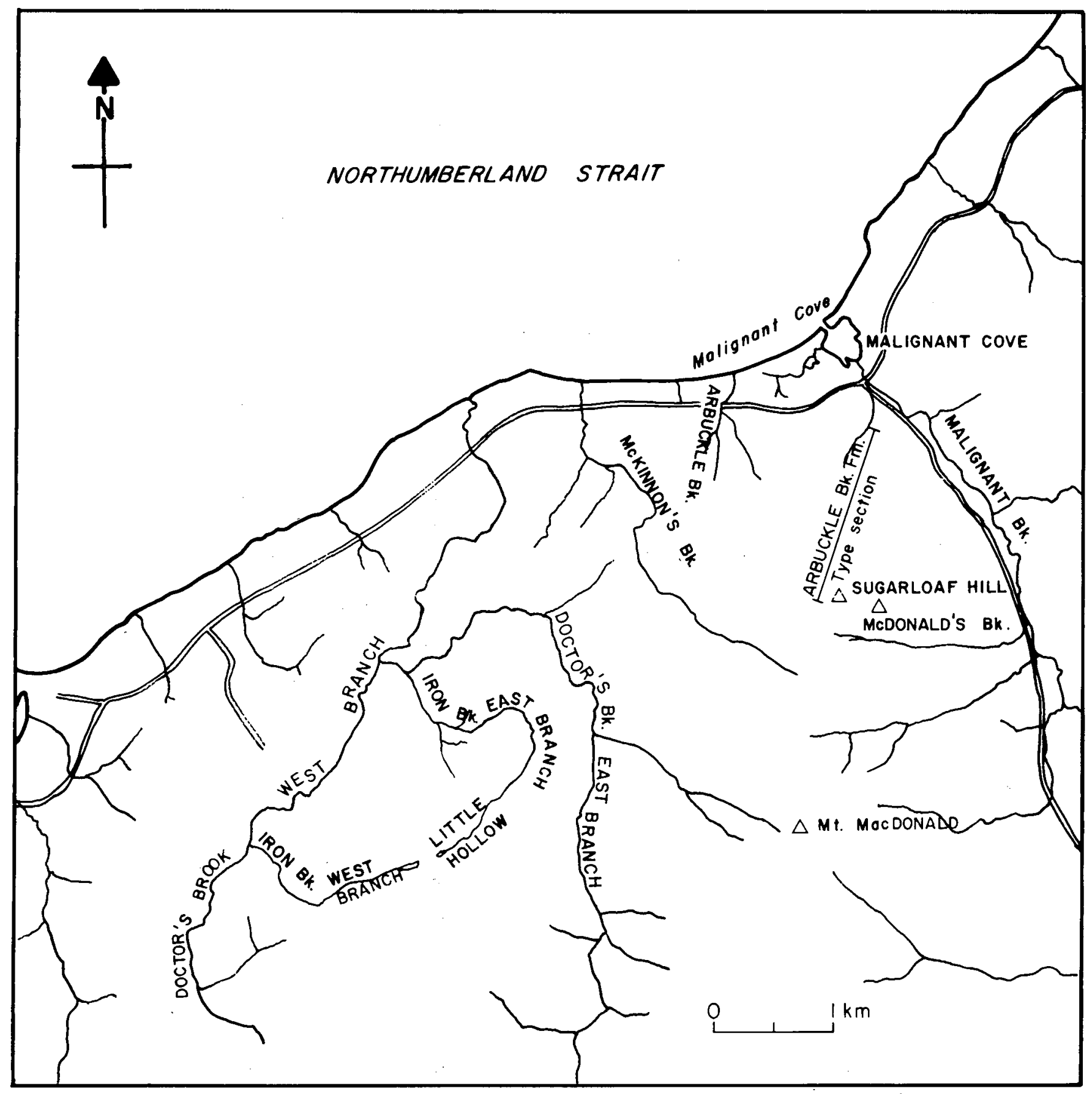

Fig. 3. Geography of the Malignant Cove area showing the locations of the place-names and type sections mentioned in the text.

sively replaced by mottled red and green, penetratively cleaved, siltstones and slates displaying cross-lamination. The colouration of these rocks is very irregular and is attributed to postdepositional reduction of originally red rocks. Some elliptical (2:1) reduction spots with subhorizontal long axes occur on the cleavage planes. These rocks are in turn overlain by a $3 \mathrm{~m}$ massive, pale pink to white quartzite, displaying load structures along its base. The quartzite is overlain by further red and green slates with fewer siltstones. Just to the east, a $1 \mathrm{~m}$ thick felsic tuff is interbedded with these slates on the northern bank of the Little Hollow, but is absent in the type section. Also, a gabbroic sill intrudes the succession here close to the contact between the Black John and Little Hollow formations. Above this sill the red slates are interbedded with fossiliferous limestone. The base of the lowest limestone defines the top of the Black John Formation.

Petrography. The rhyolitic tuff occurring at the base of the Black John Formation contains fragments and whole microphenocrysts of albite, sericitized orthoclase and angular grains of quartz. The matrix has been extensively recrystallized and consists of calcite, sericite, albite, quartz, pyrite and minor epidote.

The red conglomerates contain a variety of pebble lithologies many of which possess an inherited foliation at diverse orientations relative to the foliation in the matrix. These pebbles lie in a foliated matrix of quartz, perthitic feldspar clasts and sericite, chlorite and biotite. The Late Precambrian plutons in the 


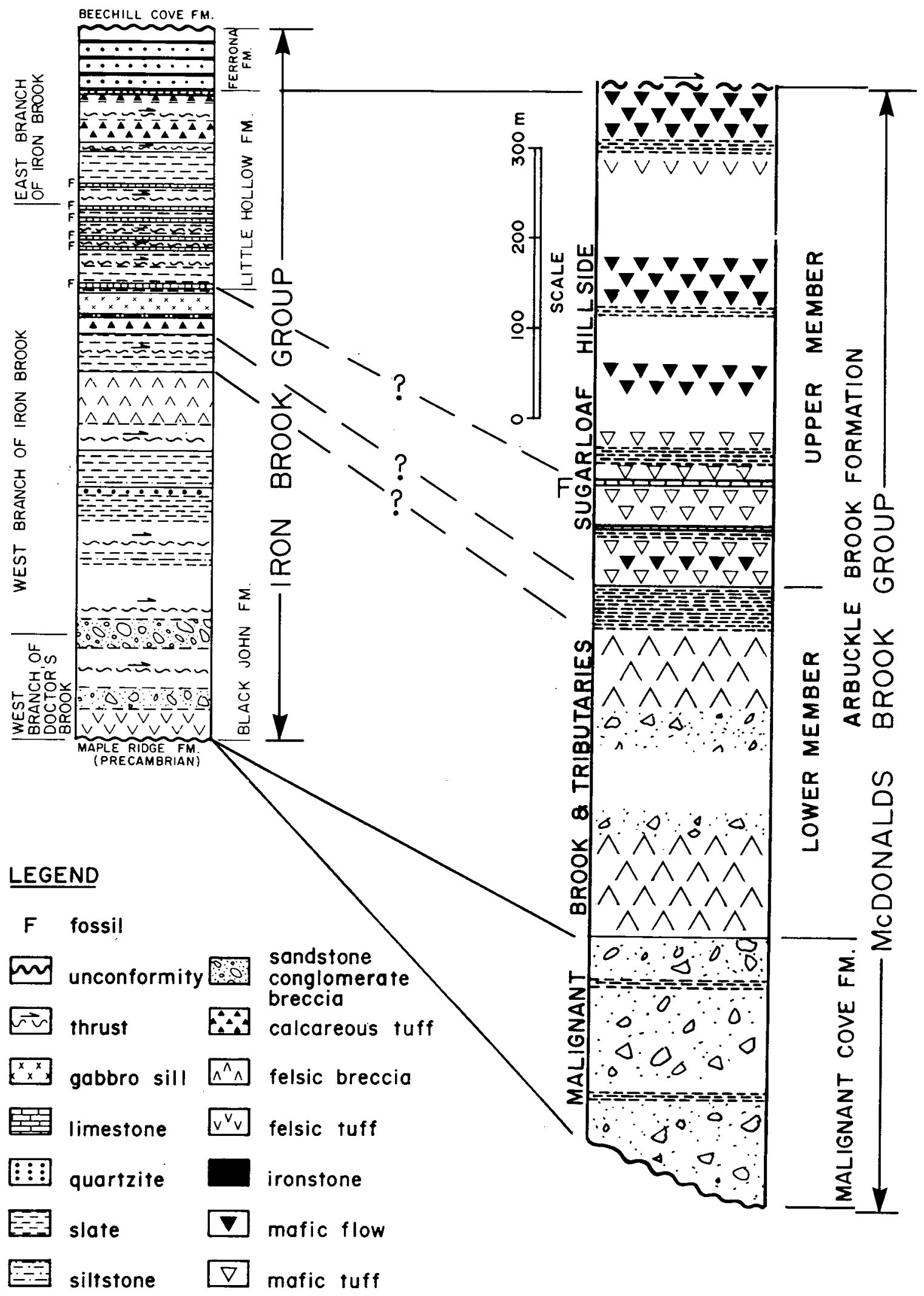

Fig. 4. Stratigraphic columns of the Iron Brook and McDonalds Brook groups. 
Avalon Zone may be the source of the perthitic feldspar clasts and graphic granite.

The slates consist of minute grains of quartz and feldspar, commonly with a hematitic coating, surrounded by aligned sericite and defining the slaty cleavage.

Age. Although the Black John Formation is unfossiliferous, it conformably underlies the fossiliferous late Early Cambrian Little Hollow Formation, and so is probably Early (to Eo-) Cambrian.

Environment of Deposition. The red colour of the conglomerates, sandstones, siltstones and slates and the lack of interbedded marine rocks suggests that the Black John Formation is terrestrial. The fining-upward character of the formation together with their primary structures indicate a fluvial environment probably in a braided river setting.

\section{Little Hollow Formation}

Field Relationships. The Little Hollow Formation is best exposed in the type section along the West Branch of Iron Brook (Figs. 1, 3, 4). It also crops out on the East Branch of Doctor's Brook and in isolated exposures around Sugarloaf Hill. The name is derived from the Little Hollow, a valley which joins the headwaters of the East and West Branches of Iron Brook. The term Little Hollow Formation was first used by Benson (1974). It is re-defined here and applied to a more restricted sequence of rocks. It consists predominantly of interbedded red slates and pink limestones, with minor calcareous tuff. The base and top of the formation are here defined respectively by the first and last occurrences of limestone. The lower contact is exposed in the west branch of Iron Brook and appears concordant and conformable. The upper contact with the overlying Ferrona Formation is exposed in both the East and West Branches of Iron Brook and is concordant.

The thickness of the Little Hollow Formation is impossible to measure due to the numerous thrusts which occur in the type section and elsewhere. In the type section, the Little Hollow Formation has a structural width of $220 \mathrm{~m}$ which decreases to as little as $100 \mathrm{~m}$ to the northeast.

In the type section, the Little Hollow Formation typically consists of 3 to $5 \mathrm{~cm}$ thick, interbedded red slates and pale pink fossiliferous limestones (Fig. 4). The red slates are similar to those in the underlying Black John Formation. The limestones are generally fine-grained and massive with abundant fossil debris. In places, nodules of limestone occur in the red slate matrix. The limestones are preferentially weathered relative to the slates. A relatively thick $(2 \mathrm{~m})$ pink limestone horizon occurs near the top of the formation. The calcareous tuffs contain finegrained green, and coarse-grained purple and grey, angular fragments up to $2 \mathrm{~cm}$ in size.

Petrography. The petrography of the red slates is similar to those in the Black John Formation. The limestones are generally very fine-grained and contain abundant ragged and interlocking grains of calcite, with minor quartz. Many of the grains are coated with hematite. Trilobites, brachiopods and other fossils were observed in thin section.

The calcareous tuffs contain clasts up to $3 \mathrm{~cm}$ in diameter set in a highly altered carbonate matrix. The clasts are predominantly composed of calcite and are often flattened with their long axes usually parallel to a well-defined foliation. The matrix consists of calcite and chlorite generally coated with hematite. The matrix is intensely deformed and displays two fabrics that intersect at an acute angle. Small $(<0.5 \mathrm{~mm})$ globules of cryptocrystalline material interpreted as volcanic clasts are also common. However, the extent of alteration and deformation in this rock is so severe that identification of the protolith remains problematical.

Age. Samples of the richly fossiliferous pink limestones discovered in 1977 have been examined by E. Landing, G. Nowlan and T.P. Fletcher. The samples yielded an assemblage of trilobites, brachiopods and problematica. The trilobites may be referred to the late Early Cambrian Callavia Zone (s.l.) typical of the Avalon Zone, and contain both cosmopolitan and provincial facies-controlled elements (Landing et al., 1980).

Environment of Deposition. The alternating red slates and fossiliferous limestones and the rapid facies changes indicate a nearshore, shallow marine environment in which seasonal fluctuations produced influxes of red terrestrial clay and quiescent, clear water periods. That this shelf was connected to larger oceans is indicated by the presence of cosmopolitan, open-ocean tribolites.

\section{Ferrona Formation}

Field Relationships. The Ferrona Formation is best exposed in the type section which is located in the East Branch of Iron Brook (Figs. 1, 3, 4). It also crops out along the track running beside the East Branch of Doctors Brook (Fig. 6), and in the many pits and trenches excavated to mine the ironstones typical of the unit. The base of the formation is defined as the top of the highest interbedded limestone and slate of the underlying Little Hollow Formation. The contact is exposed in the East Branch of Iron Brook and is concordant. The top of the Ferrona Formation is unconformably overlain by the Early Silurian Beechill Cove Formation in the East Branch of Iron Brook.

The presence of thrusts within the formation precludes any estimate of its thickness. Its structural width ranges from about 50 to $70 \mathrm{~m}$. In the type section, the Ferrona Formation consists of interbedded massive grey quartzites and at least four beds of 1 to $3 \mathrm{~m}$ thick, oolitic ironstones (Fig. 4). The quartzites are generally devoid of primary structures and their contacts with the ironstones may be either sharp or gradational. The ironstones vary from relatively pure, oolitic-pisolitic varieties to those containing much well-sorted clastic material up to $5 \mathrm{~mm}$ in size and consisting of quartz, feldspar, red slate and jasper. Inarticulate brachiopod and trilobite fragments are usually present in the ironstones.

Petrography. The quartzites consist of well-sorted, $<3 \mathrm{~mm}$, subangular to subrounded, undulose quartz grains displaying quartzose overgrowths and set in a quartz matrix. Minor hematitic alteration also is present.

The impure ironstones consists of quartz, jasper, inarticulate brachiopod and red slate fragments set in a hematite matrix. The subangular to subrounded quartz grains display many optically 
continuous overgrowths separated by thin hematitic coatings. The quartz grains often display undulose extinction and contain innumerable minute cracks filled with hematite. Thin quartz needles may also be observed extending into the hematitic matrix. This feature is interpreted as an indication of instability between quartz and hematite.

The oolitic-pisolitic ironstones are texturally distinguished from other ironstones by the relative lack of clasts. They are dominated by ooids ( $<5 \mathrm{~mm}$ ) of hematite, commonly surrounding a clastic fragment in the core.

Age. The Ferrona Formation concordantly overlies the Lower Cambrian Little Hollow Formation and is unconformably overlain by the Early Silurian (Llandoverian) Beechill Cove Formation. The ironstones contain many inarticulate brachiopods fragments identified as Obolus (Lingulobus) spissa and Lingulella (?) (Williams, 1914). Despite extensive recollecting, no specimens suitable for identification were found (G.S. Nowlan, personal communication, 1984). Unfortunately, these inarticulate brachiopods are long ranging. However, the close lithostratigraphic correlation between the Cambro-Ordovician rocks of the Antigonish Highlands and southeastern Newfoundland suggests that the Ferrona Formation is equivalent to the Bell Island and Wabana groups which contain Arenigian graptolites (Hayes, 1915; Ranger, 1979). A similar Early Ordovician age for the Ferrona Formation implies a significant gap in the stratigraphic record between it and the underlying, Early Cambrian Little Hollow Formation. The apparent absence of middle and upper Cambrian strata suggests that there is either a disconformity or thrust within the Iron Brook Group.

Environment of Deposition. The close association of orthoquartzites and fossiliferous oolitic-pisolitic ironstones suggests a marginal marine environment. The quartzites may represent beach or sand bank deposits, whereas the oolites suggest deposition in water constantly agitated by tidal currents. The pisolites may indicate the presence of blue-green algae (Dimroth and Kimberly, 1976). The oolites and pisolites may have been washed into sand bars by storm or tidal currents. An oxidizing environment is indicated by the predominance of hematite. The source of the iron is uncertain, but the high Ti and $\mathrm{V}$ content $\left(\mathrm{TiO}_{2}\right.$ ranges from 2.0 to $3.5 \mathrm{wt} \%, \mathrm{~V}$ from 200 to 400 ppm) suggest that the hematite was originally deposited as magnetite from a volcanogenic source (e.g., Miyashiro and Shido, 1975). Alternatively, the iron may have been leached from supratidal marshes surrounding the marine basin (cf. Ranger, 1979).

\section{McDonalds Brook Group}

The McDonalds Brook Group is named after the brook of that name just south of Sugarloaf Hill. Type sections for each formation of the McDonalds Brook Group occur in Arbuckle and Malignant brooks, and along the northeastern side of Sugarloaf Hill (Fig. 3).

\section{Malignant Cove Formation}

Field Relationships. The Malignant Cove Formation was first named by Williams (1914) for the red conglomerate around Malignant Cove (Figs. 1, 3). It is best exposed in Malignant Brook and its tributaries which are here taken as the type section. In the first eastern tributary from the mouth of Malignant Brook, a gap in exposure of several metres separates the lowest outcrop of the Malignant Cove Formation from the underlying Precambrian Chisholm Brook Formation of the Georgeville Group. The contact is inferred to be an unconformity because the Malignant Cove Formation rests on one of the lowest units of the Georgeville Group and contains deformed pebbles of Georgeville Group lithologies. The top of the Malignant Cove Formation is not exposed. The contact with the overlying Arbuckle Brook Formation is defined at the first occurrence of volcanic rocks (Fig. 4). Interlayering of conglomerates and volcanic rocks occurs in the vicinity of the contact, which appears to be concordant on a regional scale (Fig. 1).

The Malignant Cove Formation is approximately $300 \mathrm{~m}$ thick. It is made up predominantly of red conglomerates with minor breccias, sandstones, and slates. The clasts in the conglomerates and breccias range in size from pebble to cobble, are typically subangular and are set in a sandy matrix. The formation varies from massive, poorly bedded and imbricated clast-supported conglomerates, through planar, cross-bedded and imbricated sand matrix-supported conglomerates, to rare planar and cross-bedded sandstones and fine slates. The formation as a whole does not show any upward fining or coarsening, although both occur on an outcrop scale.

Petrography. The conglomerates contain a wide range of clasts. Mafic and felsic volcanic clasts are predominant and include altered basalt, porphyry, rhyolite and various tuffs. Clast lithologies also include green sericitic slate, red siltstone, wacke, granite, chert, jasper, perthitic feldspar and albite. Many of these clasts may be derived from the underlying Precambrian Georgeville Group, or the neighbouring Cobequid Highlands and Cape Breton Island. These clasts are set in a matrix composed mainly of quartz with minor sericite, chlorite and biotite. Cleavage in the pelitic clasts has diverse orientations relative to the fabric in the matrix. This suggests that the cleavage was present in the clast lithologies prior to their incorporation in the conglomerates.

Age. The Malignant Cove Formation was inferred to be midlate Ordovician in age by Boucot et al. (1974) and Benson (1974). Since it is unfossiliferous, its age must be deduced from its relationships with other units in the area. It postdates the Precambrian Georgeville Group and some of the deformation experienced by these rocks because it contains deformed Georgeville clasts. On the other hand, it concordantly underlies the Arbuckle Brook Formation from which late Early Cambrian fossils have been recovered. Thus, the age of the Malignant Cove Formation is probably Early Cambrian to Eocambrian.

Environment of Deposition. The red colour of the Malignant Cove Formation and the lack of interbedded marine strata suggests a terrestrial environment of deposition. The nature of the conglomerates indicates that they are fluviatile deposits probably laid down in a proximal braidplain environment. The lack of any overall fining- or coarsening-upwards may suggest that the source area was periodically rejuvenated possibly by uplift along 
faults active during the formation of the basin.

\section{Arbuckle Brook Formation}

Field Relationships. This unit is best exposed on Sugarloaf Hill, in the first western tributary of Malignant Cove Brook from its mouth, and in the area around the East Branch of Doctor's Brook (Figs. 1, 3). However, these names have been used previously, so the unit is named for Arbuckle Brook in which the unit is relatively poorly exposed. The lack of any continuous section across this unit means that the type section is composite. It is made up from sections exposed in the first western tributary of Malignant Brook from its mouth and an overland traverse up Sugarloaf Hill (Fig. 3). The Arbuckle Brook Formation is divided into two members: a lower member consisting of felsic volcanic rocks and interlayered, minor red conglomerates, and an upper member characterized by mafic volcanic rocks interbedded with relatively subordinate slates and pink limestones. The base of the formation is placed at the first appearance of felsic volcanic rocks. The contact with the Malignant Cove Formation is not exposed but appears concordant and transitional on a regional scale (Fig. 1). The boundary between the lower and upper members is placed at the base of the lowest mafic volcanic rock (Fig. 4). This boundary is not exposed but coincides with a magnetic gradient on the gradiometer map of the Geological Survey of Canada (1982). The top of the Arbuckle Brook Formation is truncated by thrusts (Fig. 1). Magnetic gradients within the upper member of the Arbuckle Brook Formation trend approximately parallel to the underlying unit boundaries suggesting a reasonably continuous sequence. The thickness of the Arbuckle Brook Formation is estimated to be about $350 \mathrm{~m}$.

The lowermost units consist of massive, subaerial felsic lithic breccias with a few interbedded rhyolitic flows and red conglomerates. A gap in exposure separates these rocks from more felsic breccias near the top of the lower member. The breccias are typically pale green and contain purple to green, angular lithic fragments up to $4 \mathrm{~cm}$ in size and plagioclase phenocrysts.

About $1 \mathrm{~km}$ north of Sugarloaf Hill, felsic volcanics of the lower member are overlain (after a gap in exposure) by green aphanitic, submarine mafic flows of the upper member. These alkalic, within-plate basalts (Murphy et al., 1985) grade laterally into hyaloclastites and minor tuffs containing elliptical porphyritic, lithic fragments $(<2 \mathrm{~cm})$, red slate and pink fossiliferous limestone. The mafic volcanic rocks are well exposed around the top of Sugarloaf Hill, while intermittent outcrops of mafic volcanic rocks occur to the south. On Sugarloaf Hill, a mafic tuff unit is interbedded with relatively minor red slates and siltstones, pink fossiliferous limestones and mafic flows. This area coincides with a high magnetic gradient that is interpreted to be due to a greater proportion of mafic rocks. Mafic dykes and gabbro stocks are spatially associated with the mafic upper member of the Arbuckle Brook Formation suggesting that they are subvolcanic feeders for the extrusive rocks. Similar mafic volcanic rocks interbedded with minor red slates also crop out in and adjacent to the East Branch of Doctor's Brook (Figs. 1,6).

Petrography. The sedimentary rocks in the Arbuckle Brook
Formation are very similar to lithologies already described from other Cambrian units. Thus, the red conglomerates are the same as those in the Malignant Cove Formation, while the red slates and pink fossiliferous limestones are identical to those in the Little Hollow Formation. These descriptions will not be repeated here.

The rhyolites consist of microphenocrysts of saussuritized plagioclase (now albite) and minor, strongly sericitized orthoclase in a fine-grained matrix of albite, K-feldspar, quartz, sericite, and chlorite with minor epidote and calcite. Thin rodlike microlites of feldspar display a good flow alignment. Quartz is typically interstitial and its shape is largely controlled by that of the feldspar. Sericite and chlorite define a non-penetrative foliation in these rocks. The tuffs consist of green to purple lithic fragments up to $3 \mathrm{~cm}$ in diameter enclosed in a fine-grained, highly altered matrix. These fragments contain euhedral albite up to $6 \mathrm{~mm}$ in length, palagonite, minor chlorite and epidote. The matrix is exceedingly fine-grained and is composed of quartz, albite and sericite with minor calcite and chlorite.

In the mafic rocks, volcanic textures appear to have been well-preserved but subsequent metamorphic events have affected the original mineralogy. The flows are generally finegrained and contain slender microlites of partially sericitized albite (which exhibits pilotaxitic texture) set in a matrix of quartz, epidote, calcite, chlorite, sphene, titanomagnetite and sericite \pm rutile. Occasional augite phenocrysts, generally altered to chlorite, may also be present. The secondary mineralogy reflects greenschist facies metamorphism.

The hyaloclastites contain mafic lithic fragments enclosed in a fine-grained, sometimes intensely altered, matrix. The fragments range from coarse ash $(1 \mathrm{~mm})$ to lapilli $(20 \mathrm{~mm})$ in length and vary in shape from subrounded or subelliptical to highly irregular. The mineralogy of the fragments and of the matrix is essentially similar to that of the mafic flows, but they are finer grained. In most fragments, albite displays a perferred flow orientation, parallel to the long axis of the fragment. This feature probably indicates a primary flattening and imparts a weak, nonpenetrative foliation. More ragged fragments tend to contain vesicles that are filled with chlorite. Hyaloclastites are distinguished from tuffs by the presence of flow textures in their matrix. However, in some samples the matrix was sufficiently altered that this distinction could not be made.

Age. The age of the Arbuckle Brook Formation is given by the late Early Cambrian fossils in the thin pink limestone interbeds, which are identical to those in the Little Hollow Formation. No fossils were recovered from the uppermost part of the unit, which could, therefore, be slightly younger.

Environment of Deposition. The geochemistry of the volcanic rocks in the Arbuckle Brook Formation suggests they were extruded in a within-plate environment undergoing a minor, localized rifting event (Murphy et al., 1985). This is consistent with the subaerial to shallow marine transition observed in the interbedded sediments of the Arbuckle Brook Formation.

\section{CORRELATIONS}

The recovery of Early Cambrian faunas from both the 
predominantly sedimentary Iron Brook Group and the mainly volcanic McDonalds Brook Group indicates that they are correlatives of one another (Figs. 1, 2). The fossiliferous pink limestones are the best marker horizons for correlative purposes (Fig. 4), although the volcanic units may also be used. However, any detailed correlation of these two groups is impossible because it is unlikely that the volcanic edifice forming the McDonalds Brook Group would be submerged at the same time as surrounding non-volcanic areas. Nevertheless, the felsic volcanic rocks in the Black John Formation may possibly be correlated with those in the lower member of the Arbuckle Brook Formation. These tentative correlations suggest that (i) the Black John Formation is equivalent to the lower part of the Arbuckle Brook Formation and possibly to part of the Malignant Cove Formation also, and (ii) the Little Hollow Formation is probably equivalent to most of the upper member of the Arbuckle Brook Formation.

These correlations suggest a major facies change from a predominantly volcanic environment in the northeast to a predominantly sedimentary environment in the southwest. This suggests that the locus of volcanism was located closer to the northeastem end of the basin. The rift axis is inferred to be parallel to the NW-trend of the facies boundary, which is also parallel to a zone of subvolcanic intrusives (Fig. 1). The facies distribution suggests that fissures parallel to the rift axis were located at the northeastern end of the basin. These fissures are inferred to be a response to stretching of the lithosphere beneath the pull-apart basin. The NW-trend of the rift axis suggests that rifting was oblique and took place by dextral movements on NESW faults which produced a pull-apart basin where the Greendale Fault curves to meet the Hollow Fault (Fig. 5).

Although, the Cambro-Ordovician rocks of the Antigonish Highlands may generally be correlated with other units in the Avalon composite terrane (Fig. 6) (Hutchinson, 1956), they most closely compare with those occurring in the Avalon and Burin peninsulas of southeastern Newfoundland (Hutchinson, 1962). Several features are unique to these two areas: (a) the pink limestones, so characteristic of the Little Hollow Formation, also occur in the Early Cambrian Brigus, Smith Point and Bonavista formations (Hutchinson, 1962); (b) bimodal, within-plate, alkalic volcanic rocks occur in the Arbuckle Brook Formation and the Middle Cambrian Chamberlains Brook and Manuels River formations (Murphy et al., 1985; Greenhough and Papezik, 1985); and (c) ironstones occur in both the Ferrona Formation and the Early Ordovician Bell Island and Wabana groups (Hayes, 1915). It is perhaps significant that the volcanic rocks in southeastern Newfoundland occur near the NE-trending axis of the CambroOrdovician basin, where rifting would be greatest. The similar nature of the volcanic rocks and the same NE-trend of the basins suggests that they may have originated by the same dextral shear mechanism. Volcanic rocks also occur in the Cambro-Ordovician sequences in the Middle Cambrian Bourinot Group of southeasterm Cape Breton Island (Hutchinson, 1952) and in the Long Reach area of southern New Brunswick (McCutcheon, 1981). However, in both of the latter areas the volcanic rocks have a tholeiitic affinity (Murphy et al., 1985; Greenhough et al., 1985), which contrasts with the alkalic nature of those in the Antigonish Highlands and southeastern Newfoundland.

\section{STRUCTURE AND METAMORPHISM}

\section{Minor Structures}

\section{D1 Structures (overthrusting and backthrusting stages in Figs, 2 and 5 )}

The first set of structures observed in the rocks are attributed to D1. In general, the earliest structures in the central and northeastern parts of the basin are attributed to the overthrusting stage, whereas the first structures in the southeastern end of the basin are correlated with the backthrusting stage. The earliest structure observed in the Cambro-Ordovician rocks is a cleavage which varies from a penetrative slaty cleavage to a fracture cleavage and is generally parallel to the bedding. This fabric is best developed in the upper parts of the Cambro-Ordovician

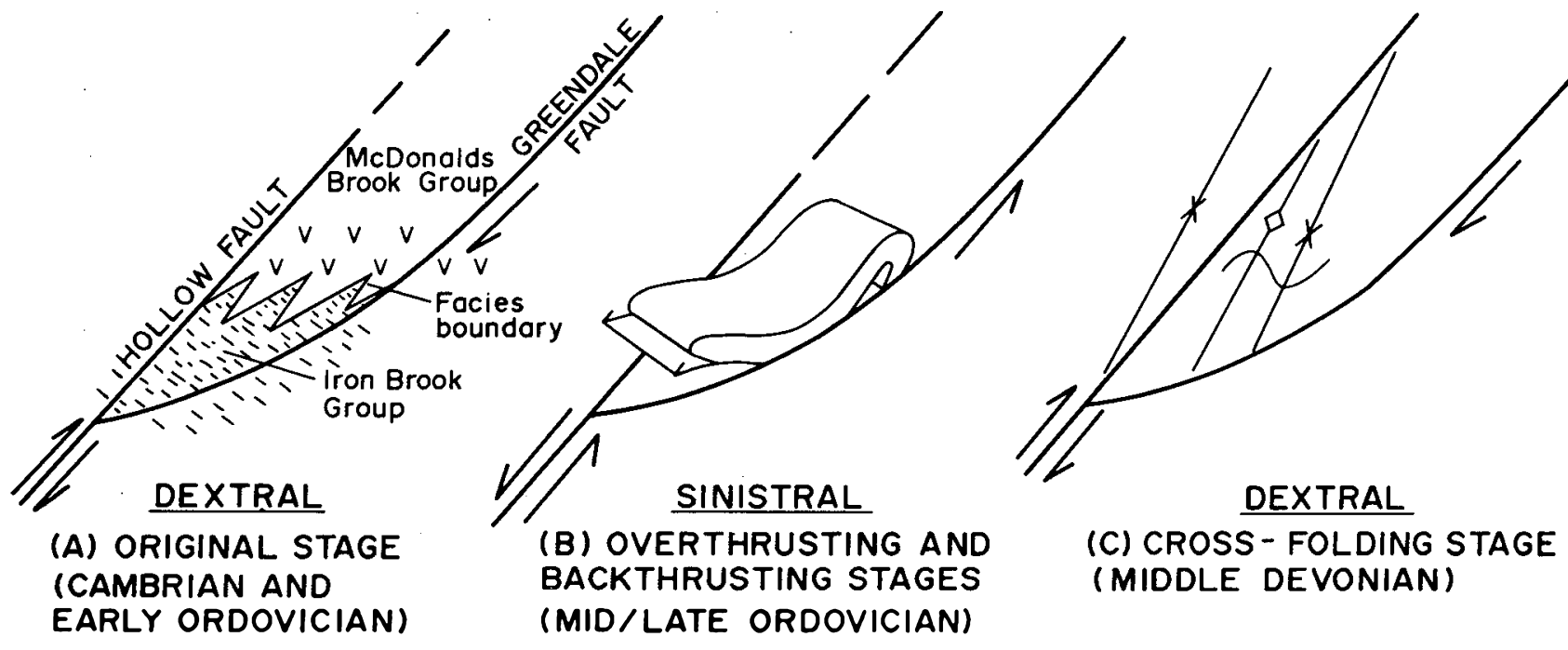

Fig. 5. Plan view shows successive stages of deformation on the bounding Hollow and Greendale faults: (a) dextral shear to form the pull-apart basin in and around which the Cambro-Ordovician rocks were deposited; (b) sinistral shear telescoping the pull-apart basin and producing the overthrusting and back-thrusting stages during D1 and D2 respectively; (c) dextral shear producing the oblique F3 folds during the cross-folding stage. 


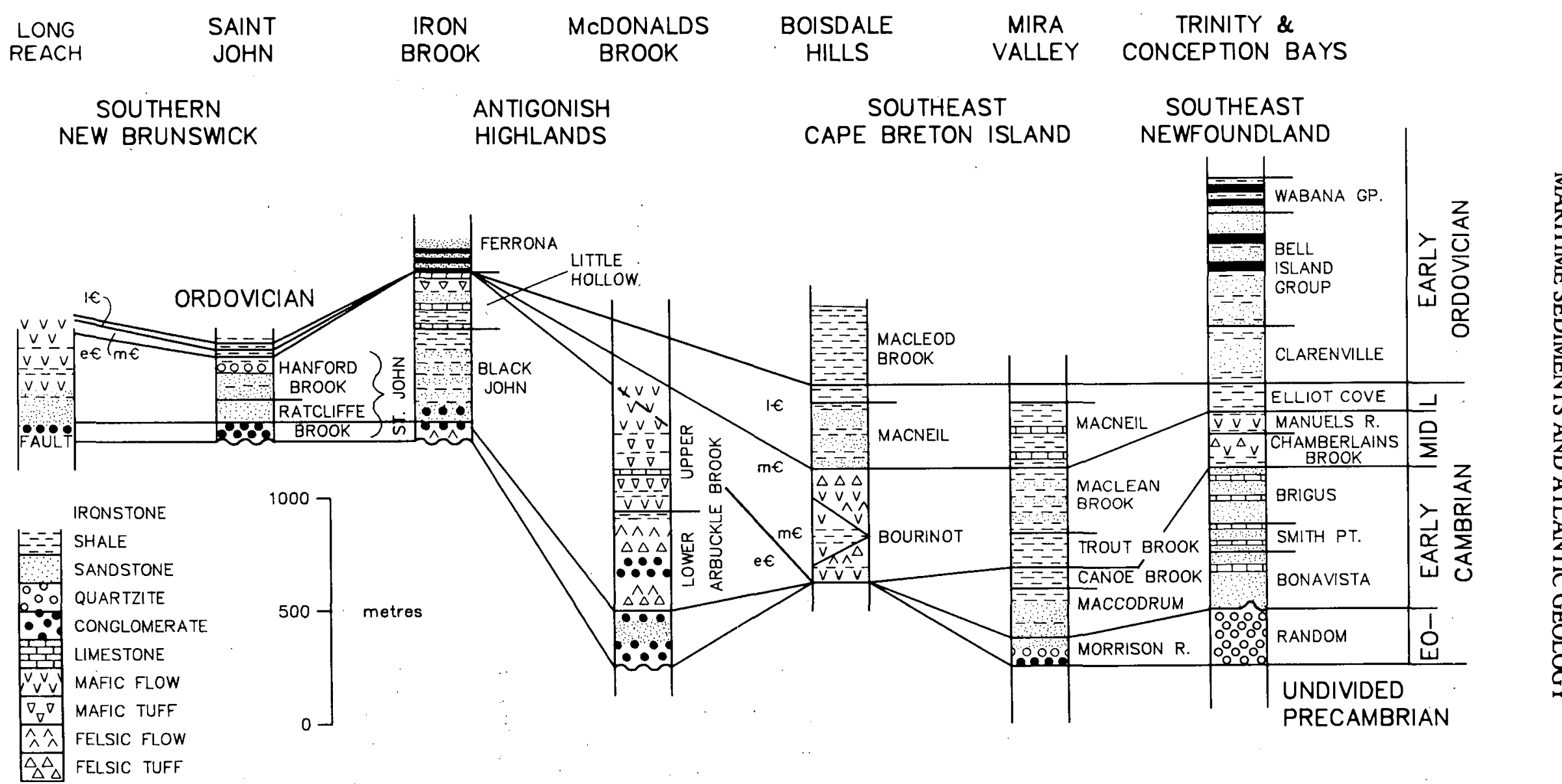

Fig. 6. Correlation chart of Cambro-Ordovician rocks in the Avalon Composite Terrane of Canada. Sections for Newfoundland are from Hutchinson (1962), for Cape Breton Island: Hutchinson (1952), and for New Brunswick: Hayes and Howell (1937) and McCutcheon (1981). 
sequence and in the basin centre. It dies out stratigraphically downwards and towards the ends of the basin (Fig. 1). Thrusts attributed to the backthrusting stage of deformation were observed at the southwestern end of the basin in the West Branch of Iron Brook. Here a transition may be observed from undeformed Black John Formation to minor thrusting and local facing reversals in the Little Hollow Formation. Kinematic indicators associated with these thrusts were not observed, presumably due to the coarse grain size of the clastic sedimentary rocks. Minor, isoclinal F1 folds were only recorded in McKinnons Brook and in the East Branch of Doctor's Brook. The one-dimensional nature of the outcrops precluded the measurement of structural data. These folds have a S1 axial planar cleavage defined by chlorite, muscovite and, locally, minor biotite. The presence of these minerals indicates an associated greenschist facies metamorphism. The mafic rocks of the McDonalds Brook Group contain the greenschist facies assemblage:

albite-quartz-epidote-chlorite-calcite-sphene \pm magnetite \pm rutile. This assemblage is consistent with greenschist facies metamorphism.

\section{D2 Structures (part of backthrusting stage in Figs. 2 and 5 )}

D2 structures are identified by their orientation and the fact that they deform the pre-existing S1 fabric. Structures attributed to this set are best developed around the central part of the Cambro-Ordovician basin. They include folds and an axial planar fracture cleavage which, although variable in orientation due to later folding, generally trends NNW-SSE (Fig. 1). Minor F2 folds occur only in the pelitic rocks and are generally chevronkink style structures which deform the S1 cleavage. The lack of metamorphic minerals associated with these structures indicates low, sub-greenschist facies temperatures.

\section{D3 Structures (cross-folding stage in} Figs, 2 and 5 )

These structures are also most common in the centre of the basin and are consistently oriented in a northeast-southwest plane on the stereonet (Fig. 1). They include ubiquitous minor folds and a steeply SE-dipping axial planar fracture cleavage. The minor folds are generally upright-asymmetric, open-close and chevron to concentric in style. They clearly deform both bedding and the $S 1$ cleavage in the Cambro-Ordovician rocks. Their relationship to the $F 2$ folds may be deduced from the major interference patterns discussed below. The lack of any significant recrystallization in the $S 3$ cleavage indicates high level, subgreenschist facies metamorphic conditions during this folding event.

It is important to note that a steeply dipping, NE-trending, slaty-fracture cleavage and associated minor folds represent the only set of structures recorded in the Silurian rocks in the East Branch of Iron Brook. These structures are correlated with those of D3 in the Cambro-Ordovician rocks. They are parallel to a major NE-SW trending syncline recorded north of the Hollow Fault (Boucot et al., 1974; Benson, 1974).

\section{Major Structure}

Conclusions about the major structure of the area relies heavily on the interpretation of the map patterns. Detailed maps of two areas critical to the determination of the major structure are shown in Figures 7 and 8. The McKinnons Brook area (Fig. 7) straddles the hinge of a major $\mathrm{F} 1$ fold in th. eastern half of the area (Fig. 1). The outcrop pattern and structural data indicate an interference pattern in which a planar, NE-trending, S3 cleavage parallel to a major, tight, F3 fold (and minor F3 fold axes) deforms a pre-existing close-isoclinal fold with a NW-trending fold axis. Bedding S0-S1 relations in the hinge zone of the major early fold indicate that it is an F1 fold. Structural readings around the F1 axial trace reveal that the early fold closes downwards while way-up structures indicate that the rocks become younger away from the F1 axial trace. This is explicable in terms of an overturned (synformal) anticline. These relationships are revealed on the A-B cross-section (Fig. 7). The planar distribution of F3 minor fold axes and S0/S3 intersection lineations reflect their superposition upon previously folded S0 surfaces.

In the East Branch of Doctor's Brook area (Fig. 8), detailed mapping reveals that the Arbuckle Brook Formation has been thrust over the Iron Brook Group previously folded by a NWtrending, F2 anticline. A thrust also cuts the Iron Brook Group beneath the thrust at the base of the Arbuckle Brook Formation. All of these structures were subsequently folded by NE-trending, steeply inclined F3 folds. These relationships are revealed in the two cross-sections (Fig. 8).

These structures are consistent with the major structure revealed by the outcrop pattern on Figure 1. Here, two NEtrending F3 fold traces traverse the area (Fig. 1, cross-section CD) and deform earlier, approximately orthogonal fold traces and thrusts. These earlier structures are best observed parallel to an F3 axial trace (Fig. 1, cross-section A-B) because the effect of F3 folding is essentially absent. Cross-section A-B, which assumes that there is only one facies change between the McDonalds Brook and Iron Brook groups reveals the structure to be a major NE-vergent recumbent fold in the Iron Brook Group that is thrust over the McDonalds Brook Group, modified by SW-vergent back-thrusting, and refolded by NW-SE folds that verge away from a central zone. In contrast, the structure is relatively simple at the NE and SW ends of the basin. The inferred sequence of events is depicted in Figures 2 and 5. The sub-Silurian unconformity cuts across the $\mathrm{F} 1$ and $\mathrm{F} 2$ structures, thereby providing an upper limit on their age. Cross-sections C-D and E-F show the final stage of the deformation in which NE-SW folds are superimposed on the pre-existing structures. 'On a regional scale, the major F3 folds appear to be localized adjacent to the Hollow Fault. The folds are also consistently oblique to the Hollow Fault in an anti-clockwise sense.

\section{Age of Structures}

The lack of D1 and D2 structures in the Silurian rocks brackets their time of deformation between the Late CambrianEarly Ordovician age of the Ferrona Formation and the Early Silurian age of the Beechill Cove Formation. The correlation of 


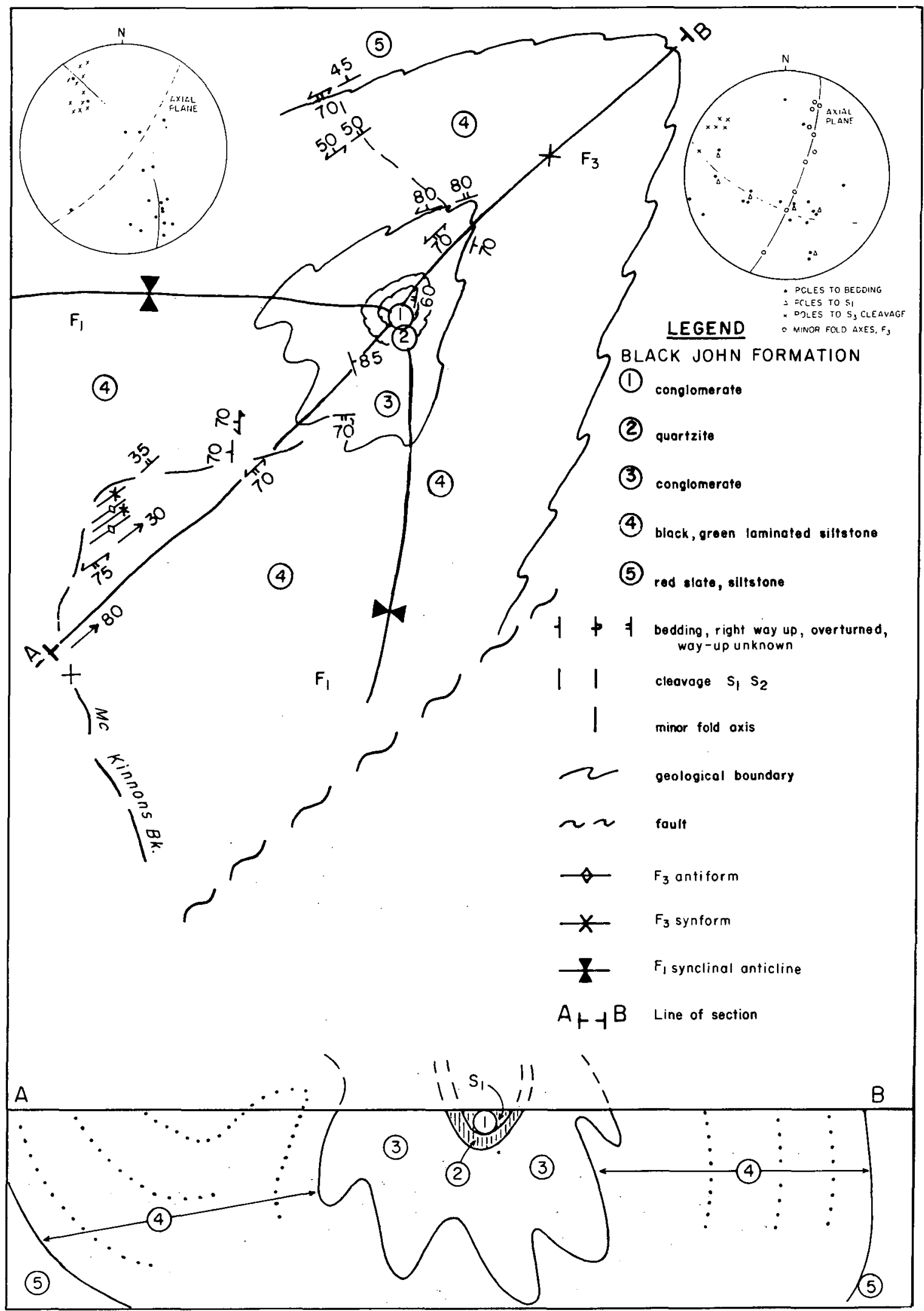

Fig. 7. Geological map of the McKinnons Brook area showing the distribution of the lithologies in northem McKinnons Brook, structural data and cross-section A-B. 

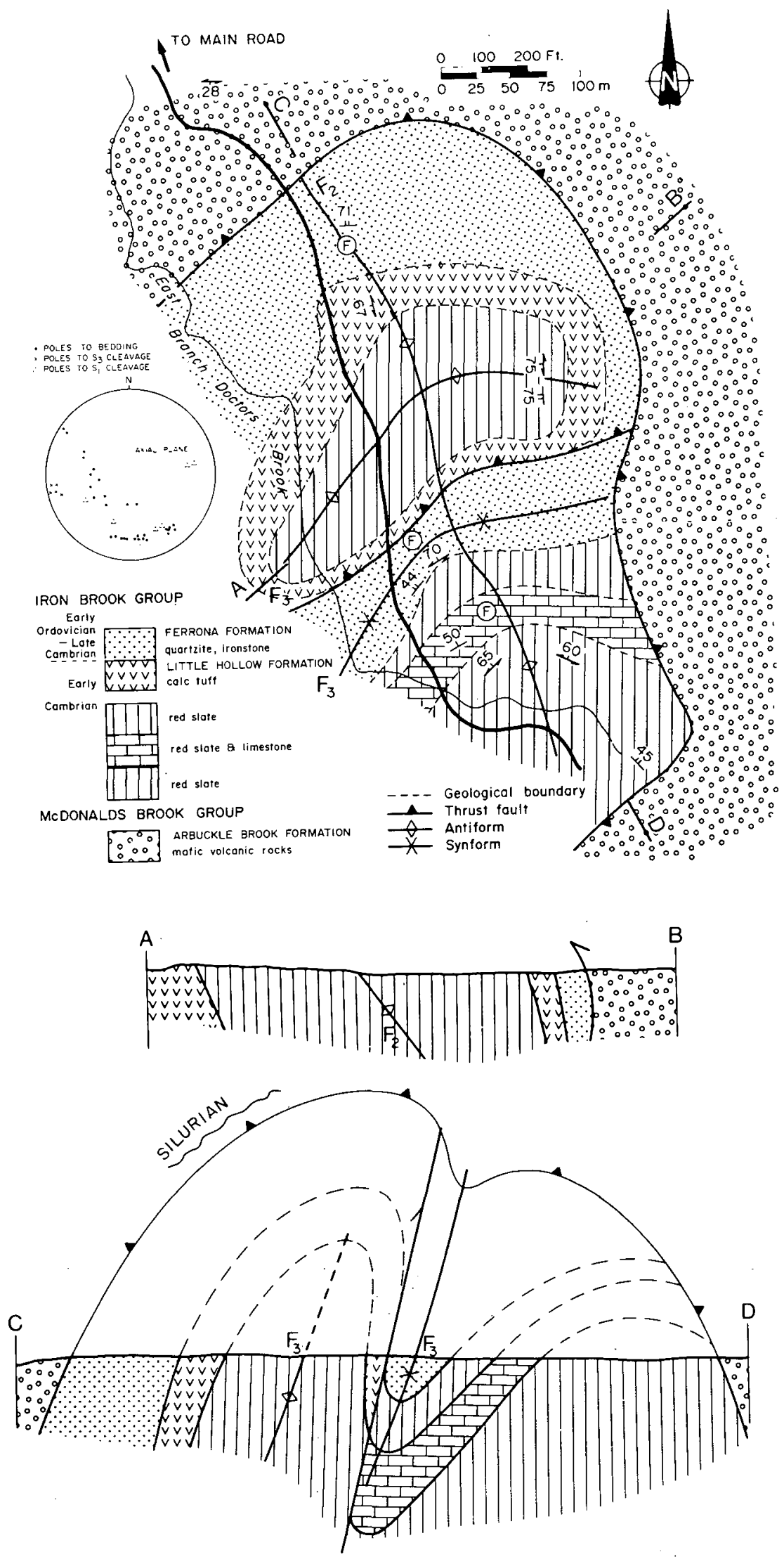

Fig. 8. Geological map of the East Branch of Doctors Brook area with structural data on a stereoplot and cross-sections A-B and C-D. 
D3 structures with those in the Silurian-Early Devonian rocks north of the Hollow Fault indicates that they are considerably younger. North of the Hollow Fault, deformed Early Devonian rocks of the Knoydart Formation are unconformably overlain by tilted rocks of the Middle Devonian McAras Brook Formation (Keppie et al., 1978). This tightly confines the time of D3 deformation between the Early and early Middle Devonian.

\section{Origin of Structures}

(Figs. 2 and 5)

The NW-SE orientations of both the F1 recumbent folds and the $F 2$ upright folds recorded in the map patterns (Figs. 1, 7, 8), the decrease in structural complexity away from the centre of the Cambro-Ordovician basin, and the opposite vergence of $F 2$ folds about the central axis, all point towards a central northwestsoutheast trending root zone acting as a locus for the deformation. It is postulated that both the $D 1$ and $D 2$ structures were produced by a single period of progressive deformation during closure of the basin. An early stage of NE overthrusting was immediately followed by a backthrusting/refolding stage (Figs. 2, 5). Such movements were localized within and telescoped the CambroOrdovician pull-apart basin about its central axis. These structures may be produced by sinistral movements on the NE-SW faults bounding the pull-apart basin. Unfortunately, the Hollow and Greendale faults are not exposed where they cut the CambroOrdovician rocks, so these inferred movements cannot be observed directly. Such localized movements would account for the limited extent of the D1 and D2 deformation.

The major F3 fold traces trend obliquely NNE-SSW across the Cambro-Ordovician basin and the adjacent Silurian rocks north of the Hollow Fault (Fig. 1). It is postulated that these folds formed during dextral movements on the northeast-trending faults (Fig. 5). This would explain their apparent localization adjacent to these faults.

\section{Correlations}

McCartney (1967) has recorded N-trending folds and thrusts in the Cambrian rocks occurring in the Avalon Peninsula of Newfoundland. These are associated with NE- and NW-trending transcurrent faults. Between Trinity and Placentia bays the NEtrending faults are dextral and the NW-trending faults are sinistral. The age of these structures can only be constrained as postCambrian; however, their orientation and sense of movement corresponds with the Middle Devonian structures in the Antigonish Highlands. On the other hand, on similar faults around Conception Bay which mainly cut Precambrian units, the apparent sense of movement is reversed: the NE-trending faults are sinistral whereas the NW-trending faults are dextral. It is possible that these movements correlate with those of CambroOrdovician age in the Antigonish Highlands.

\section{DISCUSSION}

The Cambro-Ordovician stratigraphy illustrates the pro- gressive development of a small rift basin. Initially, terrestrial sediments were deposited on a proximal braidplain (Malignant Cove Formation) eroded from mountainous areas possibly bounded by active faults. Continued rifting led to the eruption of bimodal, volcanic rocks initially into a braidplain-braided river environment (Black John Formation and lower member of Arbuckle Brook Formation) and subsequently into a shallow marine environment (Little Hollow Brook and upper member of Arbuckle Brook Formation). The absence of tholeiitic plateau basalts (Murphy et al., 1985) and the restricted occurrence of Cambrian volcanism in Nova Scotia suggests that this rift basin did not develop into a true ocean. However, the presence of cosmopolitan trilobites indicates that the rift basin was at least connected to larger oceans. The absence of mid-upper Cambrian rocks may be the result of either non-deposition or deposition and subsequent erosion. A further shallow marine incursion is indicated in the Early Ordovician and may reflect renewed rifting that in turn lead to volcanism associated with the deposition of the ironstones.

The limited extent of these Cambro-Ordovician rocks is believed to be controlled by the fault-bounded nature of the basin (Fig. 1). It is postulated that this basin formed as a pull-apart basin produced by dextral movements on the bounding northeast-southwest faults. The locus of rifting occurred where the Greendale Fault curved into the Hollow Fault. The northwestsoutheast trend of the associated Cambrian gabbro bodies may be parallel to the rift axis.

During the Ordovician, there was a reversal of the movement on the bounding faults which became sinistral. The pull-apart basin became the locus of local compression inducing basin inversion as the central basin rocks were thrust out onto the margins. This was accomplished in two stages: NE-vergent overthrusting followed by backthrusting and refolding verging outwards from the central zone as the basin closed.

During the Devonian, dextral movements are again inferred on the Hollow Fault. This accounts for the NE-trending, upright F3 folds, which occur adjacent to the fault in Cambro-Ordovician and Siluro-Devonian rocks and are consistently oriented anticlockwise of the Hollow Fault.

This sequence of events has implications for other areas in the Avalon composite terrane with comparable Cambro-Ordovician rocks and similarly oriented structures. Thus, comparable Cambro-Ordovician rocks may also have originated in dextral pull-apart rift basins, followed by sinistral deformation in the Ordovician and dextral shear in the Devonian.

\section{ACKNOWLEDGEMENTS}

The manuscript benefitted considerably from the reviews of R.D. Nance and D.G. Benson who are gratefully thanked. Funding for this project was provided by the Canada-Nova Scotia 1984-89 Mineral Development Agreement and an N.S.E.R.C. operating grant to J.B.M. We thank Marie Gillis for typing the manuscript and the drafting section of the Nova Scotia Department of Mines and Energy and Charlie Hickey for preparing the figures. 
BENSON, D.G.. 1967. Geology of the Hopewell map-area. Geological Survey of Canada, Memoir 343, 58 p.

1970. Notes to accompany the geology of the Merigomish and Malignant Cove map areas. Geological Survey of Canada Paper 70-9.

- 1974. Geology of the Antigonish Highlands, Nova Scotia. Geological Survey of Canada, Memoir 376, 92 p.

BOUCOT, A.J., DEWEY, J.F., DINELEY, D.L., FLETCHER, R., FYSON, W.K., GRIFFIN, J.G., HICKOX, C.F., MCKERROW, W.S., and ZIEGLER, A.M. 1974. Geology of the Arisaig area, Antigonish County, Nova Scotia. Geological Society of America, Special Paper 139, 191 p.

DIMROTH, E. and KIMBERLY, M.M. 1976. Precambrian atmospheric oxygen: evidence from the sedimentary distribution of carbon, sulfur, uranium and iron. Canadian Journal of Earth Sciences, 13, pp. 1161-1165.

GEOLOGICAL SURVEY OF CANADA. 1982. Experimental colour compilation (high resolution aeromagnetic vertical gradient) of parts of 11 E/9, 11 F/5, 11 F/12, Nova Scotia. Geological Survey of Canada, Map C 40079 G.

GREENHOUGH, J.D., McCUTCHEON, S.R., and PAPEZIK, V.S. 1985. Petrology and geochemistry of Cambrian volcanic rocks from the Avalon Zone of New Brunswick. Canadian Journal of Earth Sciences, 22, pp. 881-892.

GREENHOUGH, J.D. and PAPEZIK, V.S. 1985. Petrology and geochemistry of Cambrian volcanic rocks from the Avalon Peninsula, Newfoundland. Canadian Journal of Earth Sciences, 22, pp. 1594-1601.

HAYES, A.O. 1915. Geology of the Wabana iron ore of Newfoundland. Geological Survey of Canada, Memoir 78, 163 p.

HAYES, A.O. and HOWELL, B.G. 1937. Geology of Saint John, New Brunswick. Geological Society of America, Special Paper 5, 146 p.

HUTCHINSON, R.D. 1952. The stratigraphy and trilobite faunas of the Cambrian sedimentary rocks of Cape Breton Island, Nova Scotia. Geological Survey of Canada, Memoir 263, 124 p.

-1956. Cambrian stratigraphy, correlation, and paleogeography of Eastern Canada. Intemational Geological Congress, Mexico, El sistema Cambrico, 2, pp. 289-314.

- 1962. Cambrian stratigraphy and trilobite faunas of southeastem Newfoundland. Geological Survey of Canada, Bulletin 88, 156 p.

KEPPIE, J.D. 1978. Brown's Mountain Group, Antigonish Highlands, Nova Scotia - Preliminary Reassessment. Geological Society of America, Abstracts with Programs, 11, p. 19.

1982a. The Minas Geofracture. In Major Structural Zones and Faults of the Northem Appalachians. Edited by P. St. Julien and
J.Béland. Geological Association of Canada, Special Paper 24, pp. 263-279.

- 1982b. Tectonic map of the Province of Nova Scotia, scale 1:500,000. Nova Scotia Department of Mines and Energy, Map821.

- 1985. The Appalachian College. In The Caledonide Orogen, Scandinavia and related areas. Edited by D.G. Gee and B. Sturt. J. Wiley and Sons, New York, New York, pp. 1217-1226.

KEPPIE, J.D., GILES, P.S., and BOEHNER, R.C. 1978. Some Middle Devonian to Lower Carboniferous rocks of Cape George, Nova Scotia. Nova Scotia Department of Mines Paper 78-4, 37 p.

LANDING, E., NOWLAN, G., and FLETCHER, T.P. 1980. A microfauna associated with early Cambrian trilobites of the Callavia Zone, northem Antigonish Highlands, Nova Scotia. Canadian Journal of Earth Sciences, 17, pp. 400-418.

MCCARTNEY, W.D. 1967. Whitbourne Map-area, Newfoundland. Geological Survey of Canada, Memoir 341, 135 p.

MCCUTCHEON, S.R. 1981. Revised stratigraphy of the Long Reach area, southern New Brunswick: evidence for major, northwestward-directed Acadian thrusting. Canadian Journal of Earth Sciences, 18, pp. 646-656.

MIYASHIRO, A. and SHIDO, F. 1975. Tholeiitic and calc-alkalic series in relations to the behaviour of Ti, V, Ni and $\mathrm{Cr}$. American Journal of Science, 275, pp. 265-277.

MURPHY, J.B. 1987. The stratigraphy and depositional environment of upper Ordovician to lower Devonian rocks in the Antigonish Highlands, Nova Scotia. Maritime Sediments and Atlantic Geology, 23, pp. 63-76.

MURPHY, J.B. and KEPPIE, J.D. 1987. The stratigraphy and depositional environment of the Late Precambrian Georgeville Group, Antigonish Highlands, Nova Scotia. Maritime Sediments and Atlantic Geology, 23, pp. 49-61.

MURPHY, J.B., KEPPIE, J.D., and HYNES, A.J. 1982. Geological map of the Antigonish Highlands. Nova Scotia Department of Mines and Energy Map 82-5.

MURPHY, J.B., CAMERON, K., DOSTAL, J., KEPPIE, J.D., and HYNES, A.J. 1985. Cambrian volcanism in Nova Scotia. Canadian Journal of Earth Sciences, 22, pp. 599-606.

RANGER, M.J. 1979. The sedimentology of a Lower Paleozoic peritidal sequence and associated iron formations, Bell Island, Conception Bay, Newfoundland. Field Guide, Memorial University of Newfoundland, Department of Geology, 36 p.

WILLIAMS, H. 1978. Téctonic lithofacies map of the Appalachians. Memorial University of Newfoundland Map No. 1.

WILLIAMS, M.Y. 1914. Arisaig-Antigonish District, Nova Scotia. Geological Survey of Canada, Memoir 60, 173 p. 